Fourth International Conference on Sustainable Construction Materials and Technologies

http://www.claisse.info/Proceedings.htm

\author{
SCMT4
}

Las Vegas, USA, August 7-11, 2016

\title{
Determination of Thermal Properties of Hardening Concrete for Massive Nuclear Shielding Structures
}

\author{
Michał A. Glinicki'1a, Roman Jaskulski ${ }^{1 b}$, Mariusz Dąbrowski ${ }^{1 c}$, Zbigniew Ranachowski1d \\ Institute of Fundamental Technological Research, Polish Academy of Sciences, \\ 5B Pawińskiego Street,02-106 Warsaw, Poland. ${ }^{1 a}$ Email: <mglinic@ippt.pan.pl>, \\ ${ }^{1 b}$ Email: <rjask@ippt.pan.pl>, ${ }^{1 c}$ Email: <mdabrow@ippt.pan.pl>, ${ }^{1 d}$ Email: <zranach@ippt.pan.pl>.
}

\begin{abstract}
Nuclear reactor containments must maintain high durability since they restrict the spread of radiation and radioactive contamination to the general public, which could have significant consequences. The containment integrity and impermeability for potentially contaminated media is ensured using sophisticated structural and materials solutions including prevention of early age cracking of concrete. The results of numerical and experimental investigation on thermal behavior of early age concrete are presented. Concrete mixes were prepared with low-heat blended cements and various mineral aggregates. Special aggregates were selected for enhancing the radiation shielding capacity of concrete, including minerals of high atomic weight and of increased content of bound water. The proposed approach consisted of several stages, consisting mainly of measurements of the one-dimensional heat distribution in cylindrical concrete elements and solving the equation of one-dimensional heat transfer to determine thermal properties of hardening concrete. The proposed model of temperature distribution in hardening concrete is based on the non-linear inverse heat transfer problem solution. The obtained experimental results and numerically determined material characteristics are discussed in respect to the concrete mix design.
\end{abstract}

\section{INTRODUCTION}

Early age concrete, during the first days from casting, is highly exposed to the risk of cracking. In massive structural elements cracks may occur due to thermal stresses resulting from the formation of a temperature gradient caused by the heat of hydration process. The material itself cannot resist effectively the stresses due to its relatively low strength at this stage. Also steel reinforcement does not prevent early cracks because of the low adhesion forces.

Early thermal cracking of concrete increases its permeability and in many applications the impermeability of the concrete is a key requirement. These include among others biological shielding structure and foundations of nuclear reactors, [Bamonte 2014], [Mazars 2014], [Benboudjema 2008]. They are designed to prevent leakage of the radioactive elements during their predicted service life [ACI 349, 2010]. This condition is 
especially stressed in requirements for shielding structures for nuclear power reactors of the new, so called Gen III+ generation.

Since most of concrete shielding structures are usually massive structures the limits are imposed on the temperature development in the hardening concrete in order to prevent the early age cracking, [Tia 2010], [Maruyama 2015]. The contractor is required to plan the concrete work so as that large temperature differences between different parts of the structure do not arise. As a rule of a thumb the limits of a maximum difference of $15^{\circ} \mathrm{C}$ between the average temperatures in adjacent segments and $20^{\circ} \mathrm{C}$ within a cross section are used. Since early age cracking is influenced by various highly interrelated factors that affect the hydration process and stress/strain development, its behavior is highly complex and no rational methodologies for its control have been established, [Mihashi 2004]. Crack preventing procedure should also take into account the development of thermal properties of the hardening concrete, which have a vital impact on cracking risk of early-age concrete. Often to avoid thermal cracking in massive concrete elements cements of low clinker content are used and the application of supplementary cementitious materials is encouraged, [Thomas 2014]. The objective of this paper is to examine the influence of concrete mix design, potentially adequate for structural elements of nuclear power plants, on the thermophysical properties of concrete during the first 72 hours after casting.

\section{MATERIALS AND METHODS}

Materials Several concrete mixtures were tested which were divided in two groups. The first group consisted of mixtures containing the same type of mineral aggregate and variable blended cement type containing supplementary cementitious materials. Innovative blended cements were manufactured using ordinary Portland cement clinker and calcareous fly ash or blast-furnace slag of varying contents [Glinicki 2016]. The designation of ordinary Portland cement type according to EN standards was CEM I 42.5N. The designation of CEM II cements also follows the European standard, however the use of calcareous fly ash is not included in the standard definition of CEM V type. Further details on properties of blended cements containing calcareous fly ash are available elsewhere, [Dziuk 2013]. Crushed granodiorite was used as coarse aggregate and quartz sand as a fine one. Concrete mix proportions are presented in Table 1.

Table 1. Concrete mix design - series I with blended cements

\begin{tabular}{|c|c|c|c|c|c|c|}
\hline \multirow{2}{*}{$\begin{array}{c}\text { Mix } \\
\text { designation }\end{array}$} & \multirow[t]{2}{*}{ Cement type } & \multicolumn{5}{|c|}{ Constituents $\left[\mathrm{kg} / \mathrm{m}^{3}\right]$} \\
\hline & & Cement & Water & $\begin{array}{l}\text { Coarse } \\
\text { aggregate } \\
2-8 \mathrm{~mm}\end{array}$ & $\begin{array}{c}\text { Coarse } \\
\text { aggregate } \\
\text { 8-16 mm }\end{array}$ & $\begin{array}{c}\text { Sand } \\
0-2 \mathrm{~mm}\end{array}$ \\
\hline C1 & CEM I (OPC) & 400 & 200 & 625 & 615 & 580 \\
\hline C2-SW & CEM II/B S-W & 400 & 200 & 625 & 615 & 580 \\
\hline $\mathrm{C} 2-\mathrm{W}$ & CEM II/B W & 400 & 200 & 625 & 615 & 580 \\
\hline C5-SW & CEM V/A S-W & 400 & 200 & 625 & 615 & 580 \\
\hline
\end{tabular}

The second group of concrete mixtures consisted of mixtures made with the same blended cement with blast furnace slag and different types of coarse aggregate. The designation of the cement type according to EN standard is: CEM III/A 42.5N LH-HSR-NA. It has a moderate slag content (about 50\%) and is characterized by low hydration heat, high sulfate resistance and low alkali content. Special mineral aggregates were used as adequate for shielding concrete for nuclear power plant structures, i.e. barite, magnetite and serpentine 
aggregates of the maximum aggregate size of $16 \mathrm{~mm}$. Moreover, crushed amphibolite aggregate was selected as a reference aggregate as commonly used in high quality structural concrete. The mix proportions are presented in Table 2 .

Table 2. Concrete mix design - series II with special mineral aggregates

\begin{tabular}{|c|c|c|c|c|c|c|c|}
\hline \multirow{2}{*}{$\begin{array}{c}\text { Mix } \\
\text { designation }\end{array}$} & \multicolumn{7}{|c|}{ Constituents $\left[\mathrm{kg} / \mathrm{m}^{3}\right]$} \\
\hline & Cement & Water & $\begin{array}{c}\text { Amphibolite } \\
2-16 \text { mm }\end{array}$ & $\begin{array}{c}\text { Barite } \\
\text { 0-16 mm }\end{array}$ & $\begin{array}{c}\text { Magnetite } \\
5-16 \mathrm{~mm}\end{array}$ & $\begin{array}{l}\text { Serpentine } \\
2-16 \mathrm{~mm}\end{array}$ & $\begin{array}{c}\text { Sand } \\
0-2 \mathrm{~mm}\end{array}$ \\
\hline C3-A & 400 & 200 & 1284 & -- & -- & -- & 552 \\
\hline C3-B & 400 & 200 & -- & 1771 & -- & -- & 552 \\
\hline C3-M & 400 & 200 & -- & -- & 2125 & -- & 552 \\
\hline C3-S & 400 & 200 & -- & -- & -- & 1151 & 552 \\
\hline
\end{tabular}

Test procedures. Determination of the temperature distribution in the hardening cement mixture was performed with use of specially developed equipment. The main part of the equipment was a cylindrical PVC chamber of $96 \mathrm{~mm}$ inner diameter and $500 \mathrm{~mm}$ height (figure 1). It was insulated with two layers of $10 \mathrm{~mm}$ polyethylene foam with closed cells. The top of the test cylinder was left open and was only covered with thin polyethylene foil to prevent the concrete mixture from moisture loss.

To measure temperature inside the chamber four thermocouples were used. They were placed along the symmetry axis of the cylinder at the height $50 \mathrm{~mm}, 200 \mathrm{~mm}, 350 \mathrm{~mm}$ and $500 \mathrm{~mm}$ from the bottom of the chamber. Additionally the temperature of ambient air was measured with the fifth thermocouple placed above the top of the cylinder. A home-made controller and interface were used to transmit measurement data to a PC set. Values of temperature were recorded every 60 seconds with accuracy of $0.1^{\circ} \mathrm{C}$ and the test lasted up to 72 hours after casting concrete.

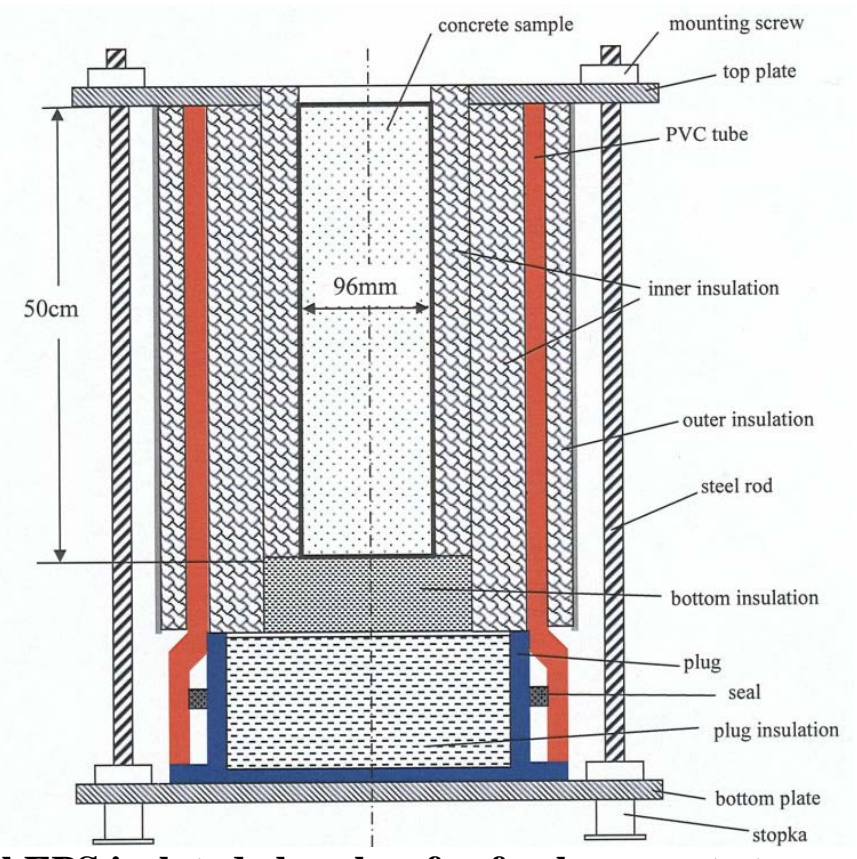

Figure 1. Cylindrical EPS isolated chamber for fresh concrete temperature testing 
Numerical procedure consisted of inverse problem solution of unidirectional heat flow in hardening concrete. Changes in properties of concrete during setting and hardening are included in the model. To determine the thermal properties of hardening concrete (effective thermal conductivity and specific heat) a developed numerical procedure was used which solved the inverse problem of unidirectional heat flow on the basis of point temperature measurements. This method was based on the paper by [Phillips 2007]. A detailed description of the numerical procedure used to solve the inverse problem can be found in [Knor 2013]. The numerical procedure allowed also for determination of the heat of hardening of tested concrete mixtures.

\section{TEST RESULTS AND ANALYSIS}

The obtained records of the temperature changes were analyzed to calculate thermal parameters of the tested mixtures. The maximum recorded temperature and time of its occurrence for concrete mixtures was determined, as well as several other parameters characterizing the rate of temperature increase and the temperature difference inside hardening concrete. The results are presented in Table 3 for the series I mixtures. In Table 4 the following set of parameters is presented for the series II of mixtures: maximum recorded temperature, maximum gradient of temperature (calculated as the difference of temperatures recorded by two sensors divided by the distance between them), maximum temperature increase (which was the difference between the minimal and maximal recorded temperature with the same sensor) and maximum instantaneous temperature increase (i.e. the maximum value of the derivative of the temperature over time). For the first two parameters the time instant of their occurrence was also established.

The temperature $(\mathrm{T})$ development in fresh concrete in time at selected location in cylindrical isolated mould is illustrated in Figure 2 and 3 for the series I and in Figure 4 for the series II. The differences in temperature at variable locations within the hardening concrete specimen illustrate the process of heat production and transfer towards the open surface during the 72 hour period of the test. On the basis of temperature measurements the time functions of effective thermal conductivity $k$ and specific heat $c_{p}$ of concrete mixtures were calculated and presented in Figures 2 and 3. The obtained solution of the heat transfer problem allowed to make a rough sketch of the function $\mathrm{S}$ describing the heat released [in $\mathrm{W} / \mathrm{m}^{3}$ ] during the hardening of concrete mixtures. The obtained functions in the graphical form are presented in figure 2 and figure 3 for the series I and in figure 4 for the series II.

Table 3. Maximum recorded temperature and time of its occurrence for selected mixtures

\begin{tabular}{|l|c|c|c|c|}
\hline $\begin{array}{l}\text { Mixture } \\
\text { Parameter }\end{array}$ & C1-A & C2-W & C2-SW & C5-SW \\
\hline $\mathrm{T}_{\max }\left[{ }^{\circ} \mathrm{C}\right]$ & 42.5 & 37.6 & 39.5 & 33.0 \\
\hline $\mathrm{t}\left(\mathrm{T}_{\max }\right)[\mathrm{h}]$ & 10.65 & 12.15 & 14.98 & 19.82 \\
\hline
\end{tabular}

Few trends can be found in results obtained for the series I. The first trend concerns the maximum recorded temperature which is decreasing with the increasing content of non-clinker components in blended cement. The cement composition affects in the same way the time of the maximum temperature occurrence. The lower was clinker content in cement the later the maximum temperature occurred.

Thermal properties changes during the hardening of the mixtures were the same in all cases. The specific heat increased and the thermal conductivity decreased. The final calculated values of the specific heat $c_{p}$ did not differ significantly and they were in the range $1.10-1.12 \mathrm{~J} / \mathrm{kg} \cdot \mathrm{K}$. The initial values were also similar to each other $(1.06-1.08 \mathrm{~J} / \mathrm{kg} \cdot \mathrm{K})$ except the value for the C1 mixture with OPC which was lower $(0.96 \mathrm{~J} / \mathrm{kg} \cdot \mathrm{K})$. If the 
thermal conductivity $\mathrm{k}$ is analyzed, it can be stated, that the decrease in its values for mixtures with blended cements are the same (about $0.8 \mathrm{~W} / \mathrm{m} \cdot \mathrm{K}$ ), but the initial values increased with the decrease of clinker content (from $1.86 \mathrm{~W} / \mathrm{m} \cdot \mathrm{K}$ to $2.35 \mathrm{~W} / \mathrm{m} \cdot \mathrm{K}$ ). In case of OPC concrete mixture the initial value of conductivity was about $1.35 \mathrm{~W} / \mathrm{m} \cdot \mathrm{K}$ and the final - about $1.0 \mathrm{~W} / \mathrm{m} \cdot \mathrm{K}$. It can be noticed that the function graphs $\mathrm{T}$ and $\mathrm{S}$ are similar in the form and location of maxima.

a)
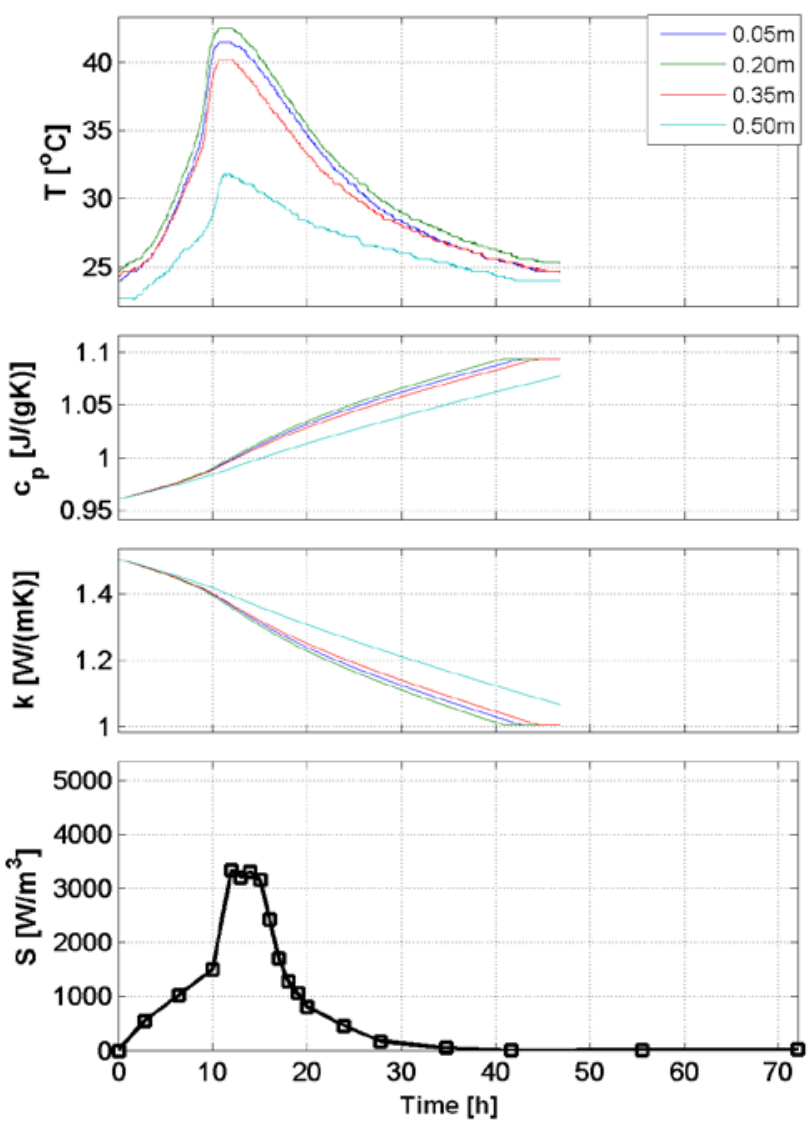

b)
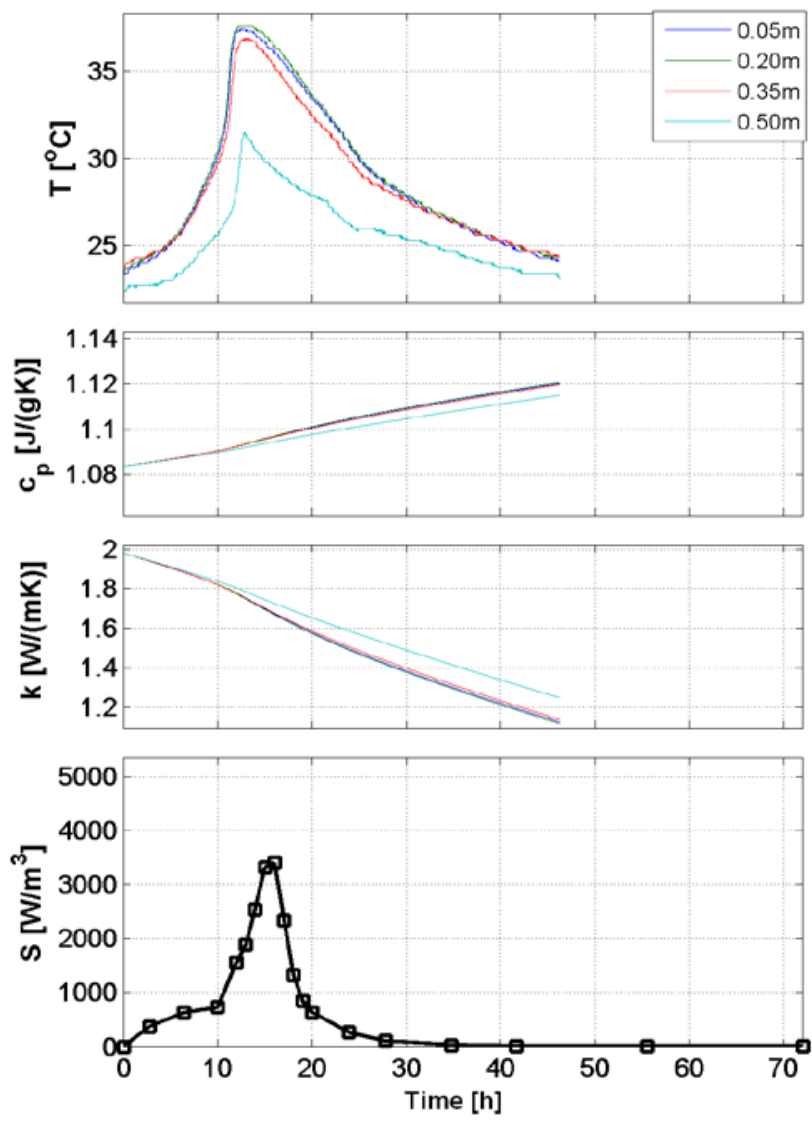

Figure 2. Temperature (T) development in hardening concrete in time at selected location in cylindrical mould and the calculated functions of effective specific heat of mixture $c_{p}$, thermal conductivity $k$ and heat release function $S$ for: a) $\mathrm{C} 1$ and b) $\mathrm{C} 2-\mathrm{W}$ concrete mixtures.

Results obtained for the series II concrete mixtures allow us to distinguish the serpentine aggregate concrete from the whole analyzed set of mixtures. For the serpentine aggregate the four maxima were observed: the maximum recorded temperature $34.1^{\circ} \mathrm{C}$ (the lowest was in case of barite aggregate $32.4^{\circ} \mathrm{C}$ ); the maximum recorded temperature difference $12.4^{\circ} \mathrm{C}$ (the minimum was for the amphibolite aggregate $10.9^{\circ} \mathrm{C}$ ), the maximum recorded gradient value $44.0^{\circ} \mathrm{C} / \mathrm{m}$ (the lowest was for magnetite $30.7^{\circ} \mathrm{C}$ ) and the highest maximum temperature increase $2.4^{\circ} \mathrm{C} / \mathrm{h}$ (the lowest was for magnetite $1.6^{\circ} \mathrm{C} / \mathrm{h}$ ).

As in the case of the series I mixtures some similarities for the function graphs $\mathrm{T}$ and $\mathrm{S}$ sketched for the series II mixtures can also be noticed. The function shape and the localization of the maximum values are similar. 
a)
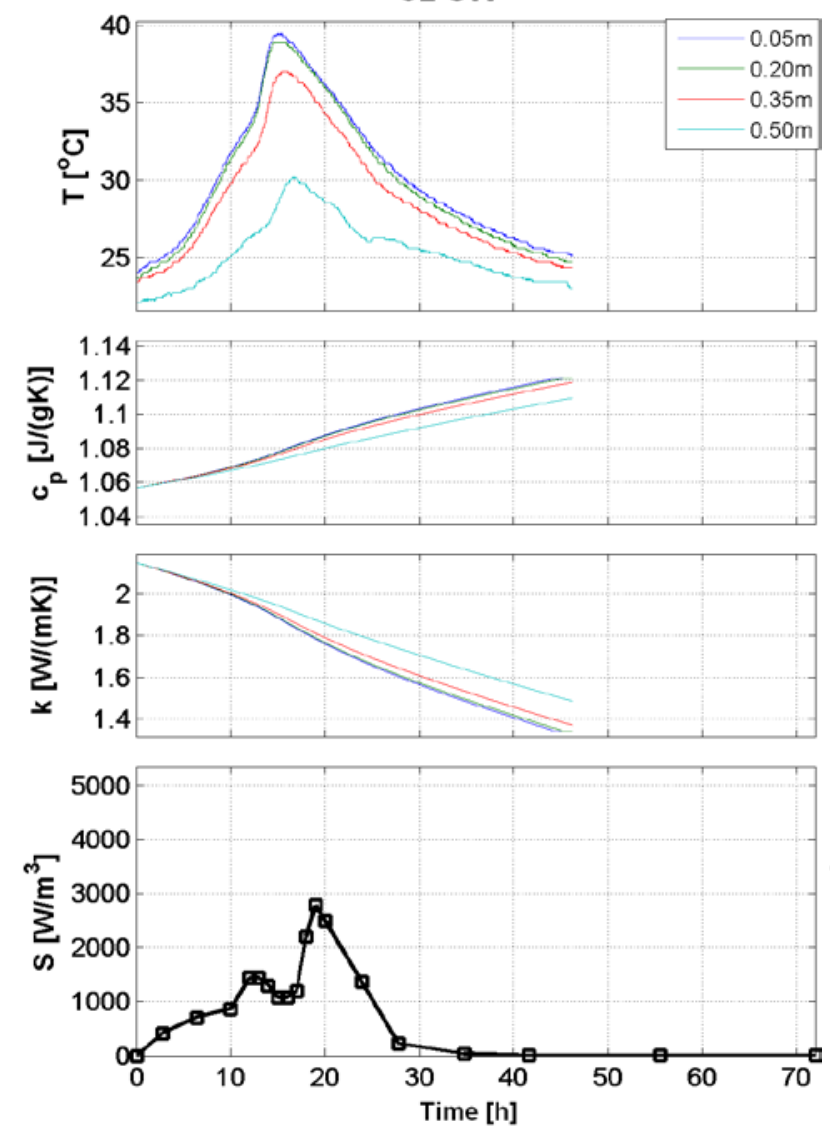
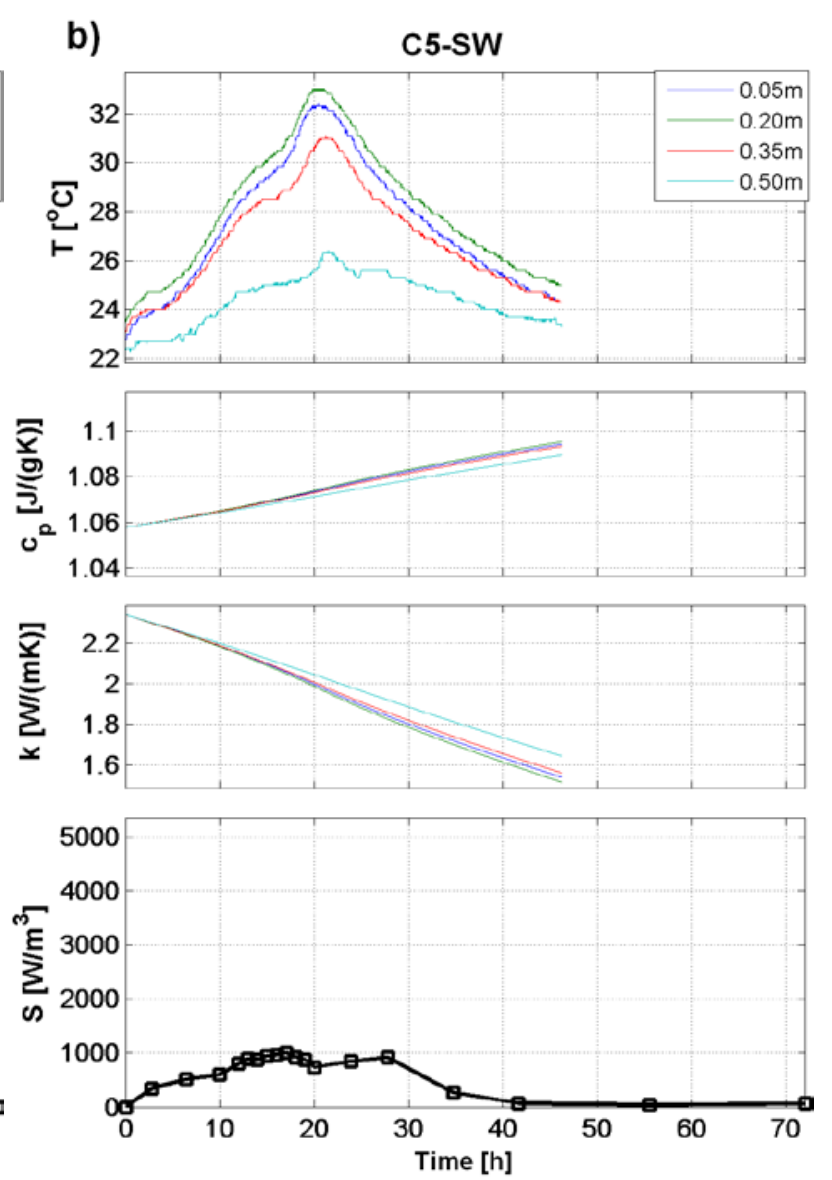

Figure 3. Temperature (T) development in hardening concrete in time at selected location in cylindrical mould and the calculated functions of effective specific heat of mixture $c_{p}$, thermal conductivity $k$ and heat release function $\mathrm{S}$ for: a) C2-SW, b) C5-SW concrete mixture.

Table 4. Thermal parameters of hardening concrete mixtures

\begin{tabular}{|l|c|c|c|c|}
\hline \multicolumn{1}{|c|}{ Mixture } & C3-A & C3-M & C3-S & C3-B \\
\hline Parameter & 33.0 & 33.4 & 34.1 & 32.4 \\
\hline $\mathrm{T}_{\max }\left[{ }^{\circ} \mathrm{C}\right]$ & 18.53 & 26.22 & 44.47 & 19.15 \\
\hline $\mathrm{t}\left(\mathrm{T}_{\max }\right)[\mathrm{h}]$ & 10.9 & 11.7 & 12.4 & 12.0 \\
\hline$(\Delta \mathrm{T})_{\max }\left[{ }^{\circ} \mathrm{C}\right]$ & 36.0 & 30.7 & 44.0 & 37.3 \\
\hline$(\nabla \mathrm{T})_{\max }\left[{ }^{\circ} \mathrm{C} / \mathrm{m}\right]$ & 10.88 & 24.68 & 45.88 & 10.47 \\
\hline $\mathrm{t}\left((\nabla \mathrm{T})_{\max }\right)[\mathrm{h}]$ & 2.0 & 1.6 & 2.4 & 2.0 \\
\hline$(\mathrm{dT} / \mathrm{dt})_{\max }\left[{ }^{\circ} \mathrm{C} / \mathrm{h}\right]$ & & & & \\
\hline
\end{tabular}



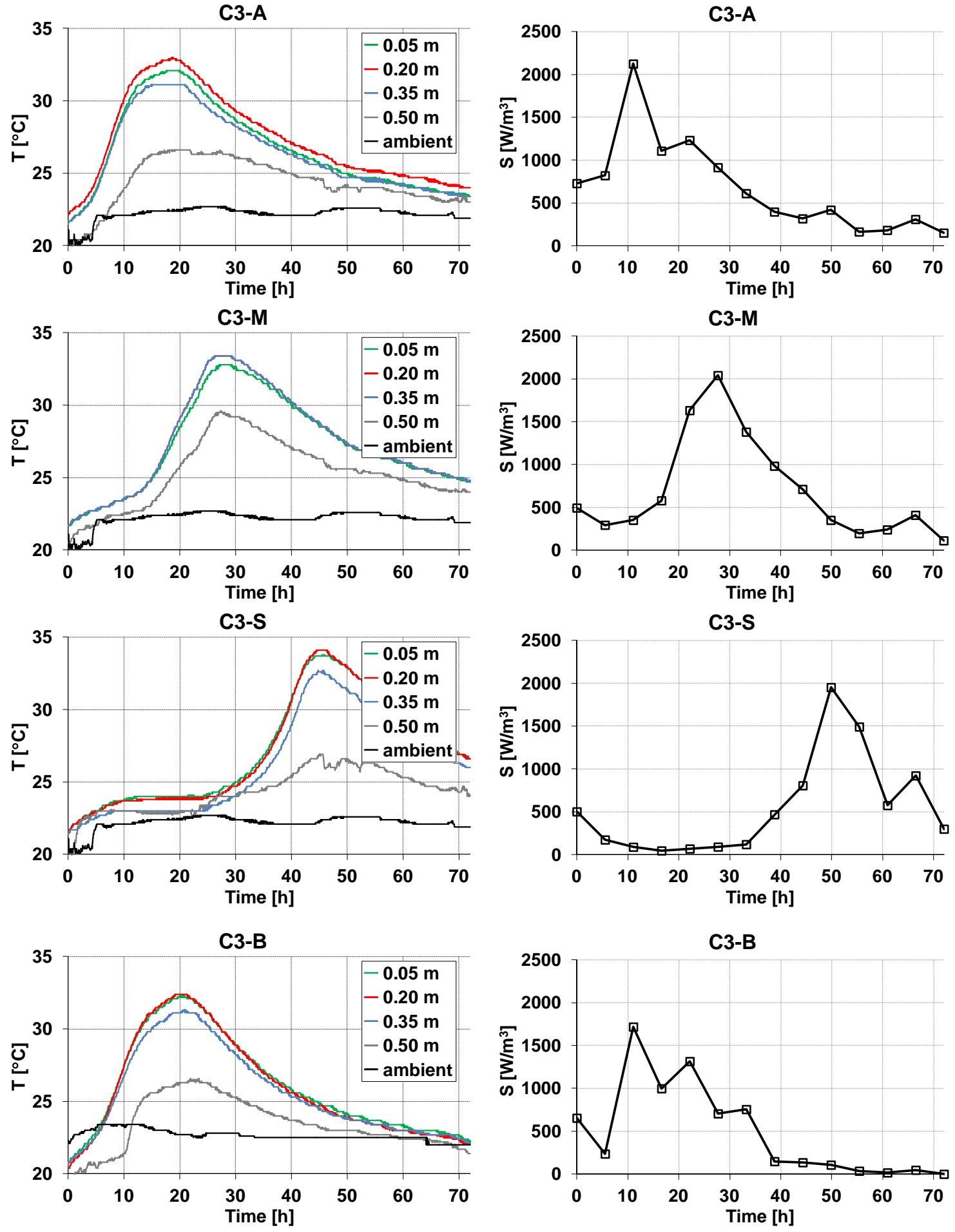

Figure 4. Temperature (T) development in hardening concrete in time at selected location in cylindrical mould and the calculated effective heat release function S for: a) C3-A, b) C3-M, C)C3-S, d) C3-B concrete mixture. 
Even with of the same binder content, the changes in aggregate type resulted in visible changes in the shape of temperature $(\mathrm{T})$ development in hardening concrete in time (figure 4). As could be expected the maximum recorded temperature shown in Table 4 was quite close for all the mixtures C3-A, C3-M, C3-S and C3-B, i.e. from 32.4 to $34.1^{\circ} \mathrm{C}$. The maximum temperature was recorded after 18.53 to 44.47 hours after concrete casting. The quickest temperature development was observed in the case of mixtures with amphibolites and barite aggregate. The most delayed temperature development was in the case of serpentine aggregate. The shape of the heat release function $\mathrm{S}$ was mirroring the differences in the temperature development curves. Observed differences in the rate of temperature development and the heat release function in hardening concrete were roughly following the proportions of the heat capacity and thermal conductivity of hardened concrete. As revealed in the previous paper [Glinicki 2015] the heat capacity was $0.78,1.07$ and $0.46 \mathrm{~J} / \mathrm{kg} \cdot \mathrm{K}$ and the thermal conductivity was $2.8-3.0,2.0$ and $1.5 \mathrm{~W} / \mathrm{m} \cdot \mathrm{K}$ for magnetite aggregate concrete, serpentine aggregate concrete and barite aggregate concrete, respectively. Although these values were experimentally determined on hardened concrete specimens with slightly lower cement content they seem to provide a fair indication of delayed heat release in the serpentine aggregate concrete.

It is clear that the use of cements of low clinker factor resulted in quite low maximum temperature and a low temperature gradient. A proof of correlation with the temperature development in full size structural concrete elements delivered in [Knor 2013] is desired for special concrete mixes containing heavyweight and hydrous aggregates. That would confirm the suitability of developed experimental and numerical test methods for the evaluation of concrete mixtures for radiation shielding structures.

\section{CONCLUSION}

The experimental and numerical test was proposed for the purpose of establishing relationships between the constituents of radiation shielding concrete mixtures and certain parameters defining the temperature distribution in concrete during the first 72 hours from mixing. The measurement procedure and the method of analysis enabled differentiation of concrete mixtures in terms of their thermal properties depending on the type of mineral aggregate. The most delayed temperature development was found in the case of serpentine aggregate. Differences in the rate of temperature development and the heat release function in hardening concrete were found to follow the proportions of the heat capacity and thermal conductivity of hardened concrete. Improved accuracy of temperature prediction in mass concrete resulting from the proposed experimental and numerical approach could be a direct benefit for design of radiation shielding structures.

\section{ACKNOWLEDGEMENT}

The financial support from the National Center for Research and Development in Poland is gratefully acknowledged (Project PBSII/A2/15/2014 "Durability and efficiency of concrete shields against ionizing radiation in nuclear power structures”).

\section{REFERENCES}

American Concrete Institute (2010) "Evaluation of Existing Nuclear Safety-Related Concrete Structures"; ACI 349.3R-02; ACI Committee: Farmington Hills, MI, p. 20.

Ballim, Y. and Graham, P.C. (2004)”A numerical model for predicting time-temperature profiles in concrete structures due to the heat of hydration of cementitious materials”, Research Monograph No. 8, Department of Civil Engineering, University of Cape Town, Cape Town, South Africa 
Bamonte, P.; Gambarova, P.G. (2014) "Properties of concrete required in nuclear power plants”. In Infrastructure Systems for Nuclear Energy; Hsu, T.T.C., Wu, C.-L., Lin, J.-L., Eds.; John Wiley \& Sons: Hobokon, NJ, USA; 409-438.

Benboudjema, F., and Torrenti, J.M. (2008) “Early age behaviour of concrete nuclear containments”, Nucl Eng Des;10 (238):2495-506.

Dziuk, D., Giergiczny, Z., and Garbacik, A. (2013) "Calcareous fly ash as a main constituent of common cements”, Roads and Bridges - Drogi i Mosty, 12, 1, 57-69.

Glinicki, M.A., Jaskulski, R., Pichór, W., Dąbrowski, M. and Sobczak, M. (2015) "Investigation of thermal properties of shielding concretes”, Proc. Int. Symp. Brittle Matrix Composites, BMC-11, Warsaw, September 27-29, 2015, 371-380

Glinicki, M.A., Jóźwiak-Niedźwiedzka, D., Gibas, K. and Dąbrowski, M. (2016) "Influence of blended cements with calcareous fly ash on chloride ion migration and carbonation resistance of concrete for durable structures”, Materials, 9 (1):18; doi:10.3390/ma9010018

Knor, G., Glinicki, M. A. and Holnicki-Szulc, J. (2013). „Determination of Thermal Parameters of Hardening Concrete by Means of Inverse Problem Solution”, Roads and Bridges-Drogi i Mosty, 11, 2, 281-294.

Maruyama, I., and Igarashi, G. (2015) "Numerical Approach towards Aging Management of Concrete Structures: Material Strength Evaluation in a Massive Concrete Structure under One-Sided Heating”, Journal of Advanced Concrete Technology, 13,11, 500-527

Mazars, J.; Capra, B.; Rouquand, A.; Pontiroli, C. (2014) “Concrete properties, safety, and sustainability of nuclear power plant infrastructures: New tools and themes for future research”. In Infrastructure Systems for Nuclear Energy; Hsu, T.T.C., Wu, C.-L., Lin, J.-L., Eds.; John Wiley \& Sons: Hobokon, NJ, USA; pp. 103-125.

Mihashi, H., and Leite, J.P. de B. (2004)"State-of-the-Art Report on Control of Cracking in Early Age Concrete", Journal of Advanced Concrete Technology, 2,2, 141-154

Phillips, S. W., Aquino, W. and Chirdon W. M. (2007). "Simultaneous Inverse Identification of Transient Thermal Properties and Heat Sources Using Sparse Sensor Information”, Journal of Engineering Mechanics, 133, 1341-1351.

Thomas, M. (2014) "Supplementary Cementing Materials in Concrete”. CRC Press, Taylor and Francis Group: New York, NY, USA.

Tia, M., Ferraro, Ch., Lawrence, A., Smith, S. and Ochiai, F. (2010)”'Developments of Design Parameters for Mass Concrete using Finite Element Analysis”, University of Florida, Gainesville, FL, USA 